\title{
Quem pode fugir dos filhos indesejados?
}

\author{
Em nome da mãe: o não \\ reconhecimento paterno no \\ Brasil.
}

THURLER, Ana Liési.

Florianópolis: Mulheres, 2009. 366 p.

Uma medida da intensidade e da configuração de um esquema de dominação é a deserção. Quem escapa pelas brechas das amarras e quem fica preso nelas. As dominações constroem seus personagens, como alianças que atravessam a produção de pessoas, mas algumas pessoas têm mais rotas de fuga à disposição. É assim com a ordem sexual patriarcal no Brasil: os pais de fato podem escapar da paternidade indesejada, as mães estão condenadas a ela. Filhos indesejados, é certo, aparecem na vida de homens e mulheres, mas a natureza da dominação masculina no Brasil é revelada pelo que ocorre depois que eles aparecem. Como defende Ana Liési Thurler, todos deveriam ter o mesmo direito de ter os filhos que desejam quando desejam, mas a estrutura do controle da reprodu- ção no Brasil faz com que o caminho da deserção da paternidade fique aberto aos homens.

O livro de Ana Liési Thurler apresenta um quadro do não reconhecimento da paternidade no Brasil, revelando algumas das rotas de fuga abertas aos homens. Essas rotas envolvem as mazelas do registro civil - por exemplo, o subregistro dos nascimentos e a batalha ingrata em torno do reconhecimento tardio -, bem como a própria produção de dados do IBGE, os limites da atuação do Ministério Público e a suspeita em relação aos depoimentos femininos. Essas rotas se inserem em um quadro em que as famílias são concebidas sobretudo no imaginário geral como girando em torno de uma figura masculina ainda que, de fato, essa figura esteja ausente na maioria dos casos. Um patriarcado sem pais em que a figura masculina é uma assombração na família, um patriarcado fantasmagórico em que cabe aos pais a rota de fuga de um papel garantido na imaginação familiar - um papel que não implica sequer a responsabilidade do registro. Trabalhar com os homens, como diz Anne-Marie Devreux em um dos prefácios do livro, significa trabalhar com suas ausências, com o campo vazio, com as não práticas. A pesquisa de Thurler investiga os rastros dessa fantasmagoria e aponta 
para o seu impacto na produção da dominação das mães e das mulheres em geral.

Thurler considera a instituição da parentalidade. A maternidade, e seu ônus sistematicamente sacralizado ou naturalizado, aparece como alternativa básica de inclusão das mulheres nas entranhas do patriarcado: a loba santificada. Os dispositivos de dominação instauram corpos femininos que estão prontos para serem lidos como se a função da maternidade estivessem inscrita neles. E a produção de corpos maternais tem sua história. Thurler se embrenha um pouco na construção de um país de filhos da mãe - na expressão apta de Lourdes Bandeira em um dos prefácios do livro -, onde os homens foram produzidos em um sistema de delírio colonizador e as mulheres instadas na direção de seres-para-afamília, com sua vida emocional e volitiva encaminhada para a privacidade e a reprodução. Emergem, contudo, outros modelos de parentalidade que contrastam com - modelo brasileiro dos filhos da mãe. A parentalidade é praticada fora do casamento, fora da família, fora da privacidade instituída do domínio das crianças como príncipes de um reino constituído e com fronteiras. Thurler examina alguns desses modelos emergentes de parentalidade no caso francês, em que a legalização do aborto em 1975 transformou em enorme medida as trajetórias abertas aos homens com respeito à paternidade.

As mães por vezes não querem o registro paterno porque a paternidade vem de estupro, abuso e violência. Nesse caso, as mulheres muitas vezes são levadas a conceber e o melhor que podem fazer pelas crianças e por si mesmas é evitar o registro do nome do pai. A maternidade inescapável faz com que elas sejam condenadas à maternidade e que os pais fiquem livres de qualquer ônus. A parentalidade, assim, fica reduzida à maternidade como se a paternidade fosse uma escolha na medida em que a maternidade não o é: tudo o que abre os braços em liberdade se apoia em outra coisa tomada como natural. Na nota 319 de seu livro, Thurler conta de um caso de um homem de 40 anos que, não se sentindo preparado para ser pai, deixou o filho nas mãos da mãe - ela natural, ele soberano. Ele conta que "ela foi muito legal comigo", já que nunca pediu nada para ele, o que pode ser entendido assim: ela respeitou sua decisão de não ser pai e aceitou sua sina de ser mãe. Um esquema de dominação carrega uma distribuição do que é matéria-prima a ser subjugada e do que tem espaços de manobra.
No Brasil a maternidade é quase compulsória para quem engravida e seu ônus é considerado como um desejo natural sacralizado. Trata-se de um desejo que é concebido como intenso o suficiente para o sacrifício de muitos outros e que já traz em seu bojo um comportamento e uma imagem - aqueles da maternidade - que tornam impossível a deserção. A deserção da maternidade é considerada comumente uma atrocidade, uma aberração e um ato contra a natureza - como se a natureza, ela mesma, apresentasse mandamentos afetivos que não pudessem ser desobedecidos. É a ditadura do instinto materno, ao lado do caráter fugidio de qualquer instinto paterno. $\mathrm{E}$, de fato, os pais e o sistema de registro desconfiam da paternidade apontada pela mãe - algum outro teste é necessário para que a paternidade seja estabelecida e é a mãe que possui o ônus da prova. A reversão do ônus, como já acontece em alguns países da América Latina, pode produzir um efeito em cascata: os homens entram em acordos com as mulheres, têm uma rota de deserção menos pavimentada e, com isso, o reconhecimento (e a divisão do trabalho e do custo de gerar e manter vivas as crianças) aumenta. Enquanto no Brasil a constitucionalidade da Lei Maria da Penha ainda não foi confirmada pelo STF, no Peru a Corte de Justiça confirmou a constitucionalidade da lei que inverte o ônus da prova.

Thurler estima que hoje cerca de 500 mil crianças no Brasil, anualmente, não têm a filiação paterna em seu registro. Ainda que muitas vezes as mães, elas mesmas, não têm interesse de registrar a paternidade - alegando que a força da lei não afetaria relevante ou positivamente o comportamento dos pais -, o sub-registro tem como consequência a imposição de um modelo monoparental nuclear que não é necessariamente da escolha das mulheres e nem está aberta a elas uma alternativa - de renúncia ou compartilhamento do ônus e dos benefícios da parentalidade. No patriarcado fantasmagórico em que vivemos - e que tem também uma marcação de classe e de raça -, os homens são sombras fugidias nas famílias, enquanto as mulheres tocam o ofício da produção de pessoas. Vale notar que - patriarcado sem pais onera as mães e, em princípio, vulnerabiliza as mulheres, já que a elas não estão abertas as rotas sinalizadas da deserção. Porém, longe de serem frágeis, elas algumas vezes tomam para si a potência que muitas vezes emerge dessas famílias-gambiarras.

O livro de Thurler contém um conjunto de recomendações para transformar a situação 
brasileira e as muitas rotas de fuga abertas aos homens. As recomendações explícitas se limitam ao escopo das políticas públicas e incluem a universalização efetiva dos direitos das crianças, a generalização dos direitos reprodutivos, a inclusão do nome do pai já no primeiro documento de pré-registro (a Declaração de Nascidos Vivos) e a inversão do ônus da prova da paternidade. A deserção da paternidade surge como um tema que aponta para o peso que a proibição e criminalização do aborto têm na estrutura da dominação masculina. Se os homens tivessem o direito de decidir com suas parceiras que filhos teriam, as rotas para escapar da paternidade não teriam todas essas linhas sinuosas que envolvem as leis, as práticas e a imaginação de uma sociedade em que a maternidade se tornou compulsória e a paternidade assumida gota a gota.

É certo que há modelos de parentalidade que passam ao largo da família e mesmo dos resquícios de potestas que ainda perduram na imagem de que os filhos são filhos (dos mesmos pais e mães) para sempre. Modelos de homoconjugalidade vêm suscitando crescentemente a busca e a implementação de outros modelos de parentalidade, menos centrados na família como núcleo da vida afetiva, menos centrados nas estruturas de pouca participação dos homens na produção de pessoas, menos conformes às normas heteropatriarcais. Se a família desaparece, desaparece também com ela essa concentração retumbante de delírios privados em que os desejos não são forças centrífugas que estabelecem conexões, mas pressões concentradoras que trazem as vidas emocionais, os desejos, as riquezas e os prazeres para dentro de núcleos instituídos. E nesse bojo concentrador, os filhos, etiquetados por um nome de família. No entanto, o livro de Thurler procura desvelar a específica engenharia que abre caminhos para que a paternidade - mas não a maternidade - seja objeto de deserção no Brasil.

Hilan Bensusan Universidade de Brasília 